\title{
EUROPEAN SPINE JOURNAL MAX AEBI AWARD FOR CLINICAL SCIENCE 2015/2016
}

\section{Maverick total disc replacement in a real-world patient population: a prospective, multicentre, observational study}

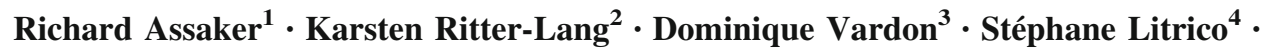

Stéphane Fuentes $^{5} \cdot$ Michael Putzier $^{6} \cdot$ Jörg Franke $^{7} \cdot$ Peter Jarzem $^{8}$.

Pierre Guigui $^{9}$ - Gérard Nakach ${ }^{10}$ - Jean-Charles Le Huec ${ }^{11}$

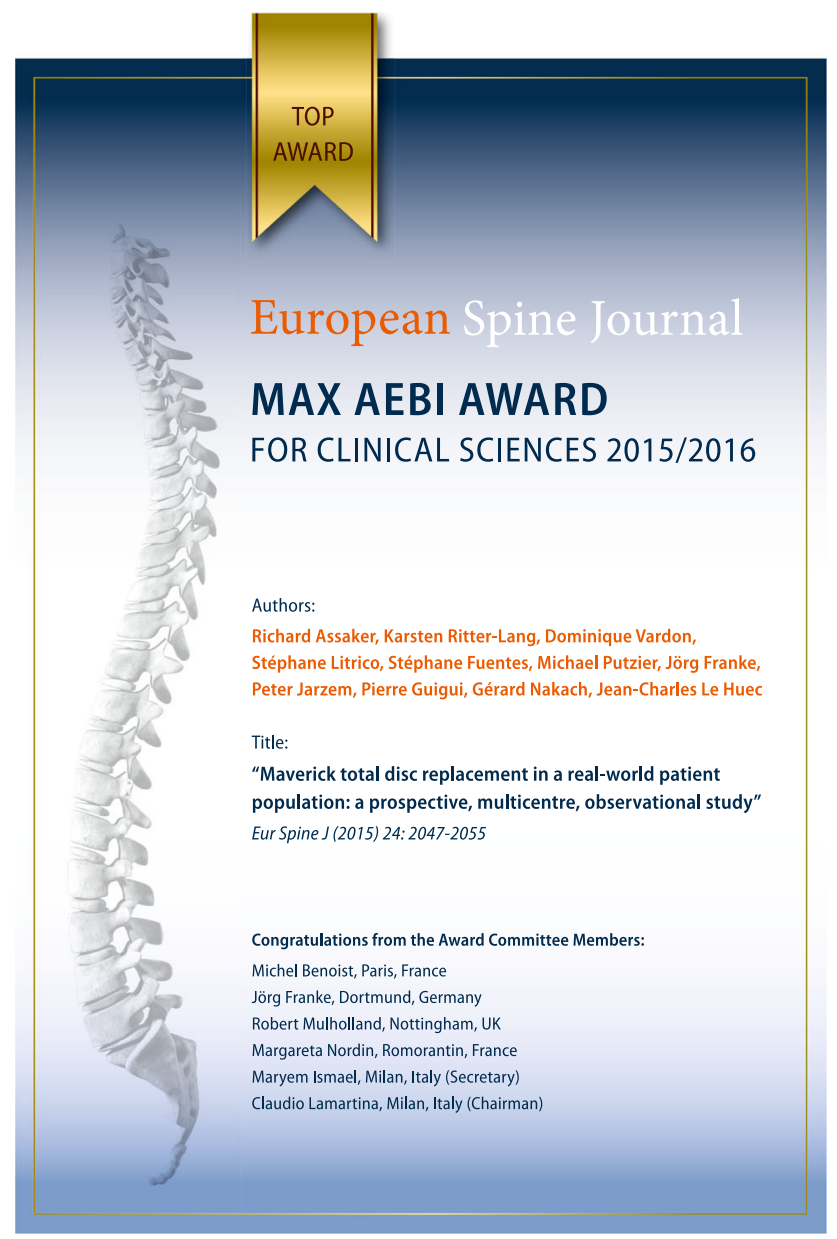

The online version of the original article can be found under doi:10.1007/s00586-015-3918-x. 